\title{
隠岐・西ノ島における漁業の展開と新規就漁のあり方
}

\section{The Present Conditions of Fishery and its Employment Structure in Nishino-shima Island, Shimane Prefecture}

\author{
大 呂 興 平 \\ (東京大学大学院 総合文化研究科)
}

Graduate Student, School of Arts and Science, University of Tokyo

1.はじめに

2. 西ノ島の地域概要と漁業の就業構造

（1）西ノ島の地域概要と漁業

（2）沿岸漁船漁業の内容と就業状況

（3）巻き網船団と雇用システム

3 . 西ノ島の漁業就業者の就業形態と後継者問題

(1) 西ノ島における漁家の就業パターン

(2) 西ノ島の後継者問題の様相

（3）新規漁業就業者不在の原因

4. I 夕ーン就漁の要因と今後の展望

(1) I ターン事業の概要と成果

（2）Iターンによる就漁の成功の要因

（3）Iターンによる就漁の可能性と課題

5.むすび

\section{1. はじめに}

わが国離島部の多くでは高度経済成長期以降, 都市部への人口流出が進行し，深刻な過疎問題 に直面することになった。離島部では一般に， 平地・盆地部や都市近郊の農村部とは異なり, その隔絶性の高さと人口規模の低さゆえに工場 進出やモータリゼーションの恩恵を受けること は少なく, 巨額の公共投資による公共土木, 公 的サービス産業, 従来からの 1 次産業以外には めほしい産業が成立しなかった。高度経済成長
期以降常に，地域社会の存続が脅かされてきた といえよう。

今後, 国家財政の逼迫によって, 公共投資に 大きく依存しているこれらの地域社会・経済の 維持が困難になることを考慮すれば，必然的に 地域資源を利用した 1 次産業に目をむけなけれ ばならないが, このなかでも漁業は, 離島部に おいて農林水産業販売額の $65 \%{ }^{11}$ を占好きわ めて重要な産業である。離島部の地域社会の動 向や今後のあり方を読みとるには，基幹産業で ある漁業の展開に注目して考察することが重要 である。

近年の全国的な漁業の動向としては, 若年齢 層の不足と高齢化がきわめて深刻化している。 例えば，沿岸漁業の漁業就業者を見ると，昭和 28 年の約 80 万人をピークに減少を続け，平成 9 年には 27 万 8 千人にまで減少しているし，漁家 の子弟が漁業を敬遠し若年層の参入が低水準に とどまる一方で, 高齢化が進行し60歳以上の男

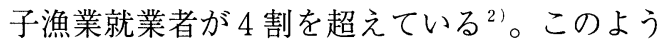
な状況は多くの離島部でも例外ではない。他の

\footnotetext{
1) 平成 10 年 離島統計年報による。

2) 平成11年『漁業白書』, 農林統計協会, 1999, p284
} 
就業機会に乏しい離島の地域社会にとっては， 漁業後継者の不在はすなわち, 地域社会の存続 が困難になることを意味しており，今後の漁業 就業のあり方について注意深く見守る必要があ る。

ところで, 漁業後継者が充足されないなかで, 近年, 後継者の確保ルートとして都市住民の I ターンによる新規就漁が期待されている ${ }^{3 !}$ 。自 然志向の高まりや就業に対する価值観の多様化 のなかで, 都市住民にも漁業に参入する希望を 持つものが増えてきたからである。このような 動きは農業においても見られ4), 例えば田畑・ 村松・両角編の農学加の一連の研究 ${ }^{5)} に$ 見ら れるように, 都市住民を受け入れる新規参入対 策のあり方が, 具体的な事例をもとに農業経営 構造や就業構造, それらの地域性などを意識し ながら検討されはじめており，国のレベルから も新規就農を支援する施策や枠組みが徐々にで はあるが具体化されつつある ${ }^{6)}$ 。現在, 漁業に おいてもこのような枠組みが不可欠になってい るといえるが, 加瀬 ${ }^{7)}$ が指摘するように, 漁業 の世帯継承の論理や経営体の構造は, 農業と大 きく異なる点には注意が必要である。例えば漁 業の場合, 恒常的な賃労働に勤務しながらの操

3) 例えば平成 10 年の『漁業白書』では, 漁家出身 者の就業促進で担い手を補うことが困難だとして， 水産高校生はもとより, 漁家出身者以外から漁業 に取り組もうとする意欲ある若者を積極的に受け 入れる必要性を示している。

4) 例えば, 田畑保「新規就農の新しい動きと就農 支援の課題」,『公庫月報』平成11年12月号, 1999 年。

5) 田畑保 - 村松功巳 - 両角和夫編『日本農業の担 い手問題と担い手対策』, 農林水産省農業総合研究 所, 1996年

6) 田畑は前掲 4 のなかで，このような事例として， 就農支援資金制度の新設や，就農準備校の開設， 畜産経営りース制度の導入などを挙げている。

7) 加瀬和俊『沿岸漁業の担い手と後継者』, 成山堂 書店, 1988年
業は不可能であり，高度経済成長期に農業に見 られた兼業機会の増大による所得向上という図 式は一般にはあてはまらない。したがって，都 市住民や漁家の子弟以外の新規就漁のあり方を 漁業経営の実態に即して分析する必要性が大き いといえる。

しかしながら実際にこれを問題意識の中心 に捉えた研究は, 島 ${ }^{8)}$ によるもの以外に主なも のは見あたらない。島は, 都市住民や漁家の子 弟以外の地域住民の就漁によって地域漁業が活 性化した事例をもとに，21世紀漁業の担い手と して彼らに大きな期待を寄せ, 彼らを積極的に 受け入れるような「開かれた地域漁業」の必要 性を強調しているが, このようなIターンによ る就業が, 地域のいかなる社会・経済的条件下 で，いかなる就業構造のもと可能になり，それ は地域漁業, ひいては地域社会全体にどのよう な意味を持ち, I ターンの確保の可能性とその 限界はどこにあるのかといった具体的な分析に ついては, さらなる研究の積み重ねが必要な状 況にある。

こうしたなかで, 都市からのI ターン者を漁 業就業者として大量に呼び込むことに成功して いる離島が存在する。隠岐・西ノ島では平成 7 年にIターン者を募集して以来, 現在まで家族 も含めると実に 70 人近くの都市住民が島内に定 着しており, 新規就漁と地域社会・漁業のあり 方を探るには格好の題材といえよう。本研究で は上述の問題意識のもと, 西ノ島漁協正組合員 の約 7 割を対象にその家族構成や漁業労働力, 漁種や後継者の有無について聞き取り調査を行

8) (1)島秀典「若年漁村就業者の漁業就業選択」『漁 業経済研究』第38巻第 2 号, 1993年

(2)島秀典「地域漁業・漁村の新たな担い手」(地 域漁業学会編『漁業考現学』農林統計協会, 1998 年) 
い，以下の課題に即してこの問題を考察するこ とにした。

考察にあたっての課題は全部で 3つある。ま ず第 1 に, 現在の西ノ島漁業の就業構造と漁業 就業者再生産のあり方を把握し，それらに現在 いかなる問題が生じてきているのか, 現出して いる「後継者問題」とその原因を明確化する。 第 2 に，I ターン者の就業はなぜ可能になり， それら「後継者問題」の解決にどのように意味 があるのか明らかにする。第 3 の課題は，他の 離島をはじめとする地域社会においても，どの ような条件下で I ターンが可能になり，それが どのような意義を持つのか, ある程度一般化す ることである。

本稿は 5 章から構成される。本章で基本的な 問題意識を呈示したのに続き，第 2 章では西ノ 島の概要を把握するとともに，西ノ島の地域社 会の中での漁業の位置づけ，漁業を取り巻く環 境を確認する。第 3 章では，先に挙げた 1 つ目 の課題に対応すべく, 西ノ島の漁業従業者につ いての聞き取り調査に基づき，その就業パ夕ー ンをいくつかに類型化する。第 4 章では， 3 章 で明らかになった就業パターンを念頭におきな がら，今後の漁業の展開と問題点を担い手の面 から考察する。そして，2つ目の課題に対応す ベく，I ターンによる従業者確保の動きを踏ま え，これらが西ノ島の地域漁業や社会に持つ意 味やその可能性を検討する。第 5 章では，今回 の調査で得られた知見をまとめ, 他地域におい てもある程度一般化しうる点を考察し，3 つ目 の課題に対する結論を引き出したい。

\section{2. 西ノ島の地域概要と漁業の就業構造}

（1）西ノ島の地域概要と漁業

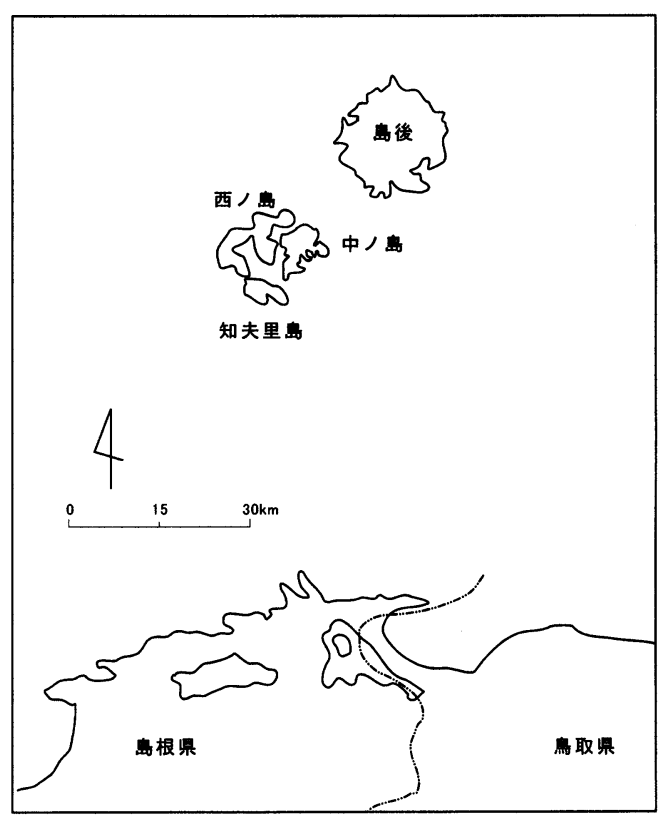

第 1 図 西ノ島位置図

西ノ島は, 島根半島の北東 $40 \sim 80 \mathrm{~km}$ 沖に浮 かぶ隠岐群島の中の 1 つである（第 1 図）。1 島で 1 町を形成し，人口4,094人，世帯数 1,716 世帯 ${ }^{9)}$ の島であるが，入口は減少を続け，高齢 化率 ${ }^{10)} も 30.6 \%$ と非常に高い。地形的には高低 起伏が激しく, 山地丘陵が錯綜しているために 耕地は限られ，広大な丘陵地が伝統的に放牧利 用されている。気候では夏涼しく冬暖かい海洋 性気候とされているが，冬には強い北西季節風 が吹き付け，時化る日が多くなり，体感温度は 低い。フエリーは久航を繰り返し，文字通り日 本海の孤島となる。親類縁者は正月よりも盆に 帰省し，島の人口は倍以上に膨れ上がる。

西ノ島の主な産業としては漁業, 畜産業, 観 光業が挙げられる。漁業は年間42億円の水揚げ 高があり，島根県下でも有数の漁業基地である。

平成 10 年 12 月の西ノ島町住民基本台帳による。

10) 高齢化率は65才以上の人口を総人口で除したも の。 


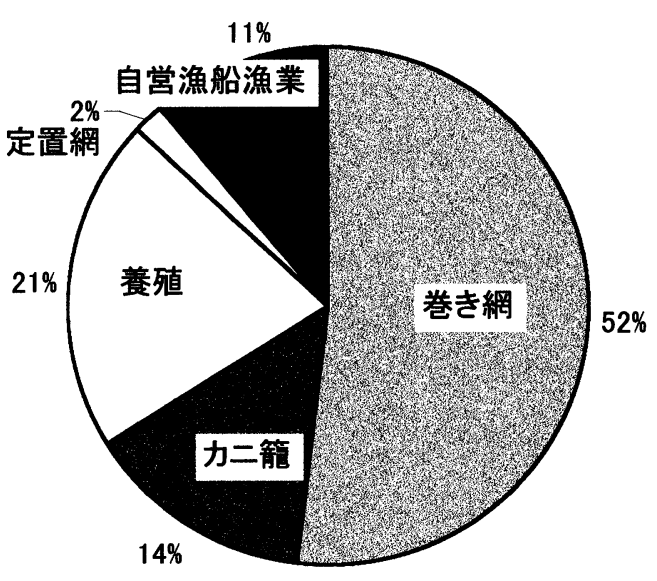

第 2 図西ノ島における漁業種類別漁獲高 資料: 平成 10 年度 浦郷漁協「業務報告書」より

これに対して畜産は 1 億 2 千万, 観光業でも 1 億〜 2 億程度の売り上げであり, 漁業が地域の 基幹産業として重要な意味を持っていることが 分かる。だが，最盛期の水揚げ高が 65 億円にも のほっていたことを考慮すると，近年の漁業の 不振は否めない。それと対応するように漁業従 事者も減少している。西ノ島漁協の組合員資格 の取得は容易で，1戸に 1 組合員といった規定 もないため，親子や夫婦が両方漁業に従事する 場合などは，概して両方とも組合員になってい るのであるが, 浦郷漁協 ${ }^{11}$ 漁協正組合員は現在 約 300 人, 准組合員は約 600 人であり, 正組合員 のほうが多かった従来とは状況が逆転している。

西ノ島の漁業には，会社組織で営まれる巻き 網, カ二籠, 定置網, 養殖業などと, 漁家単位 で営まれている刺し網，釣り，採貝・採藻など がある。ここで漁業種別の水揚げ高に注目する

\footnotetext{
11) 西ノ島には浦郷漁協と黒木漁協の 2 つが存在し ているが，郷浦漁協が 40 億程度の水揚げがあるの に対し，黒木漁協はわずか 2 億円程度しか水揚げ がない。ここでは浦郷漁協の実績を，西ノ島全体 の状況として見ることにする。
}

と, 西ノ島の漁業の特性が浮き彫りになる（第 2 図)。まき網漁業が西ノ島の全水揚げ高の52 \%を占め, その次に養殖約 $21 \%$, 力二籠漁業が 約14\%と続くが, これらはほぼ会社組織で行わ れているものであり, 西ノ島の水揚げの 8 割以 上は漁業会社によるものであると言ってよい。 一方の自営漁業の水揚げ高は一本釣り, 刺し網, 採貝など主要なものを挙げても 1 割程度である。 このように西ノ島では水揚げのうえでは, 漁業 会社なかでもまき網船団が地域漁業の中心的な 位置を占めており，多くの従業員を雇う基幹産 業となっている。

しかしながら, 漁業従事者数に注目すれば, 地域社会に扮ける沿岸漁船漁業の意味も決して 無視できないことが分かる。確かに浦郷漁協の 正組合員の半数の約 150 人は船団従事者で, 養 殖や定置網の職員なども含めると雇われ漁業者 が多くを占めている（西ノ島の場合, 船団で従 事している者には，就業して一定期間の後に， 正組合員資格が認められる)。しかしながら， 正組合員の残りの 100 人近くは自営漁業者であ り，さらに准組合員まで含めて考えれば自営漁 業者の方が多数を占めている事実を見落として はいけない。自営漁業も水揚げ高では小さくて も, 多くの世帯の生計戦略にとって何らかの役 割を担っていることが想像できる。

これらを踏まえ, 以下では, 沿岸漁船漁業の 内容と就業状況, 漁業会社の内容や雇用システ ムについて把握する。

\section{（2）沿岸漁船漁業の内容と就業状況}

西ノ島で漁家によって行われている沿岸漁船 漁業としては, 釣り, 刺し網漁業に加えて, サ ザエ・アワビを主要な対象とする「かなぎ漁業」 と潜水漁が主要なものである。第 3 図は西ノ島 


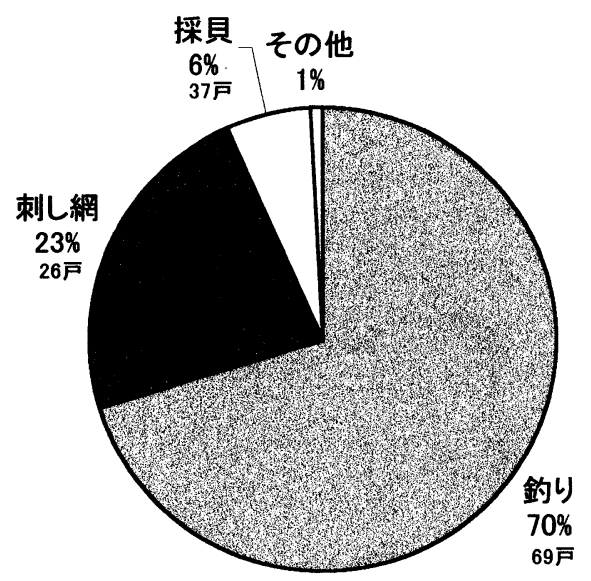

第3図 西ノ島における沿岸漁船漁業の漁種別漁獲量内訳 資料：平成 8 年度「島根県農林水産統計年報」 注）戸数はその漁種を主とする漁業経営体数を示す

で行われている漁業のうち, 沿岸自営漁船漁業 によって営まれている漁種のみとりあげ，その 水揚げ量の内訳と, 主に就業する漁家数を示し たものである。

釣りは周年的に営まれ, イカ, 夕イ, メバル などを中心としながら, 季節によって多様な魚 種が漁獲される。漁船の大きさは $1 \mathrm{t} \sim 5 \mathrm{t}$ 程 度とさまざまで, 漁獲量も経営体によって幅広 いが，海上作業のほとんどは男性 1 人によって 行われ，労働投入を軽減すれば高齢者でも従事 するのが容易である。

刺し網漁業は $5 \mathrm{t}$ 前後の漁船でハマチやメジ ロ，トビウオなどを漁獲するもので，この場合 にも通常は海上では男性 1 人が作業することが 多い。刺し網は漁獲量が不安定であり，釣りゃ 採貝・採藻も組み合わせて通年で作業する場合 が多い。

かなぎ漁業は小型の動力船または船外機船を 用い，箱メガネで海中をのぞきこんでサザエや アワビを見つけ，それらを船の上から先端に鈎 をつけた笔で漁獲するという漁法である。アワ ビは10月〜11月，サザエは 5 月〜 6 月が禁漁期
であるが，それ以外の時期は自由に漁獲が許さ れている。海上作業は男性 1 人によって行われ る場合がほとんどであり，比較的重労働でなく 技術や経験の蓄積が漁獲を左右するため，高齢 でも営まれやすい。

一方, 潜水漁は, 海中に潜って直接アワビ . サザエを漁獲するもので，潜水技術と体力があ れば，かなり効率のよい漁種である。10年ほど 前から解放されたものであるが，乱獲を招きや すいため漁獲期間・時間が制限されている。7 月中旬〜 9 月中旬のみ，正午から午後 5 時まで の解禁であり，通年にわたって行うことはでき ない。

全体的な傾向としては，小規模漁船による釣 りや採貝の占める割合が多く，1経営体あたり の漁獲高もかなり小さい。女性の海上労働は一 般的ではなく，西ノ島では漁船漁業の海上作業 は 2 人以上で営まれることは少ない。

これらの漁場はいずれも島の周辺一円であり， 組合員であればどこで漁獲してもよい。

\section{（3）巻き網船団と雇用システム}

西ノ島の会社組織による漁業のなかでも巻き 網漁業は最も規模が大きく, 島内 5 つの経営体 で 6 カ統により営まれ, 全部で 160 人以上の従 業員を抱える。巻き網船団は 1 力統 20 数名の船 員を擁し, 網船 1 , 灯船 4 , 運搬船 1 の計 6 隻 の船から構成されており, その中で個々の乗組 員の役割分担が行われている。夜間の操業であ り, 夕方出漁し数時間かけて沖合まで行き，イ ワシ，アジ，サバなどの回遊魚を漁獲したのち， 漁獲物を積んだ運搬船を残して早朝に帰港する 作業が毎日繰り返される。毎週土曜日は定休日 で，時化による休みも少なくないため，出漁日 数は年間180日から 210 日前後である。 


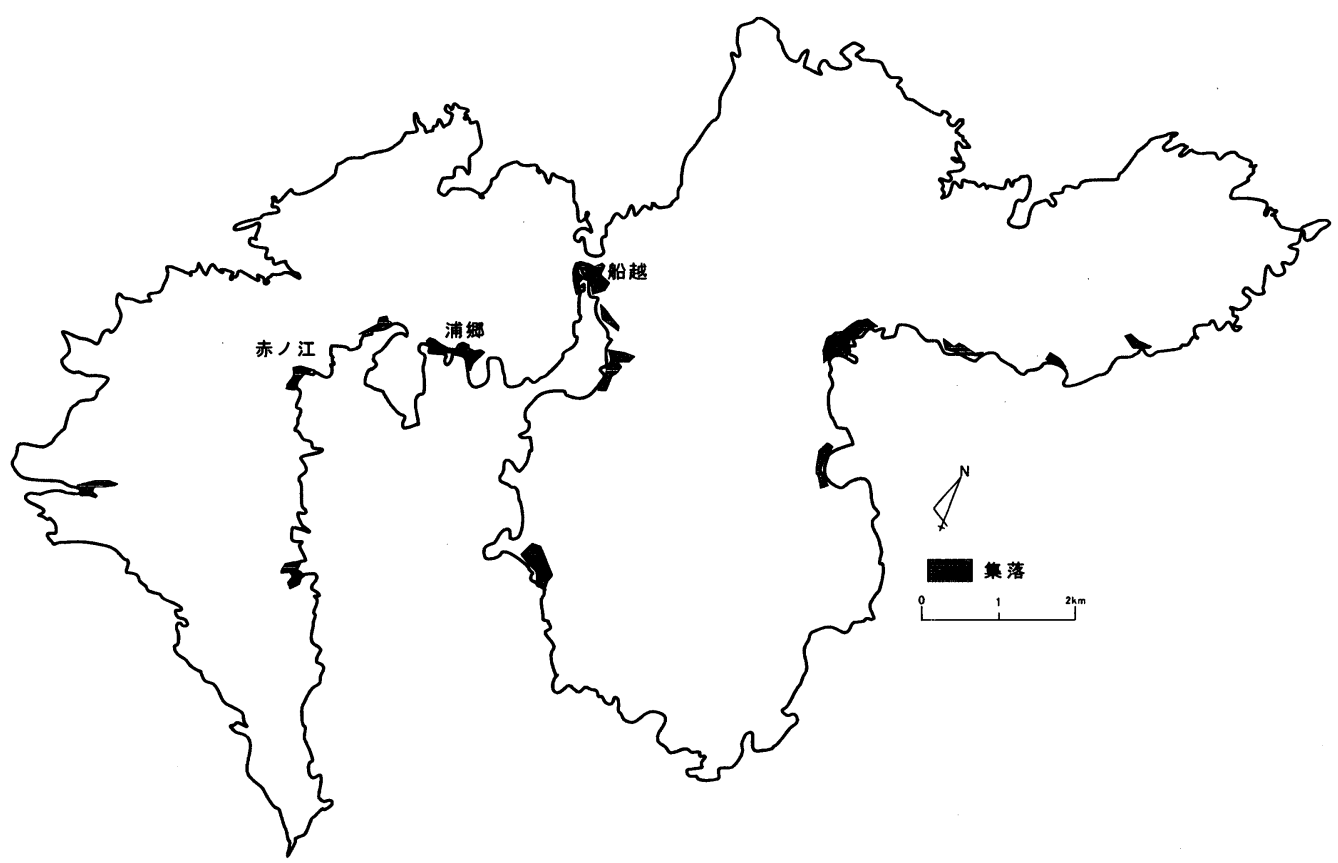

第 4 図 西ノ島集落図

船団の給与体系は年功的賃金制度をとらず, 役職者に対する歩金はあるものの, 全従業者が 基本的に同一賃金を受領する。したがって, 船 団に入って 1 年目から, 諸手当込みの月収で 20 数万円が保証され，これに加えてその時の漁獲 高に応じた歩合金も給付されるため，年によっ ては700万円程度の年収が実現できる。作業の 経験が無くても給料は保証されているうえ, 作 業を同僚や先輩に教わるので, 経験者の参入は 容易である。また船団に属していれば一定期間 経てば正組合員資格が与えられるため, 素潜り などに従事することも不可能ではない。しかし ながら，年功的賃金制度が採られていないため， 一般には加齢とともに他産業に対する賃金面の 優位性は相対的に低くなっていくことになる。 なお，船団に一定期間従事し引退すると，55才 以降に年 200 万円以上の手厚い年金が支給され， 引退後はこれが大きな収入になる。
これ以外のカ二籠漁や定置網，養殖業など会 社組織による漁業も，まき網船団員ほどではな いものの, 比較的高位安定的に給与が支給され る。

\section{3. 西ノ島の漁業就業者の就業形態と後 継者問題}

（1）西ノ島における漁家の就業パターン 本研究では, 西ノ島の漁業就業者の就業パター ンや就業者の再生産のメカニズムを把握すべく, 平成11年 2 月， 6 月の 2 回にわたり現地調査を 行なった。まず西ノ島の中でも正組合員数が多 い赤ノ江, 船越, 浦郷の 3 集落をとりあげ, そ こに在住する浦郷漁協正組合員全員の漁法，世 帯構成, 漁業後継者の有無などを集落の区長に 対する聞き取りによって逐一調査した。集落の 位置図は第 4 図，概要は第 1 表のとおりである。 この 3 集落には漁協正組合員の約 7 割にあたる 
第 1 表 調查集落の概況

\begin{tabular}{|c|c|c|c|c|c|c|c|c|c|c|c|c|}
\hline & \multirow{2}{*}{ 世帯数 } & \multirow{2}{*}{ 人口 } & \multirow{2}{*}{ 漁家数※ } & \multirow{2}{*}{ 立地する主要産業 } & \multicolumn{7}{|c|}{ 規 模別 所有漁 船 数 } & \multirow{2}{*}{$\begin{array}{l}\text { 正組合員の } \\
\text { 平均年齢 }\end{array}$} \\
\hline & & & & & $0 \sim 1 \mathrm{t}$ & $1 \sim 2 t$ & $2 \sim 3 t$ & $3 \sim 5 t$ & $5 \sim 10 t$ & $10 t \sim$ & 計 & \\
\hline 赤ノ江 & 119 & 293 & 40 & 漁業·畜産 & 17 & 19 & 2 & 0 & 0 & 0 & 38 & 59.9 \\
\hline 船越 & 179 & 525 & 36 & 漁業 & 62 & 43 & 18 & 29 & 9 & 1 & 162 & 59.2 \\
\hline 浦郷 & 522 & 1495 & 134 & 漁業・商業・観光関連・公共サービス & 33 & 54 & 6 & 15 & 7 & 1 & 116 & 55.7 \\
\hline
\end{tabular}

※漁業正組合員がいる世帯 (世帯数・人口は西ノ島行政資料より)

資料：町行政資料および漁協資料による

注）正組合員には船団に属し漁船を持たないものがいる一方，正組合員でなくても船を持つ世帯も存在することは注意が必要 である。

船越の漁船所有数のデー夕は存在しなかったため，それを含んでいる美田地区の数值を代わりに使用した。

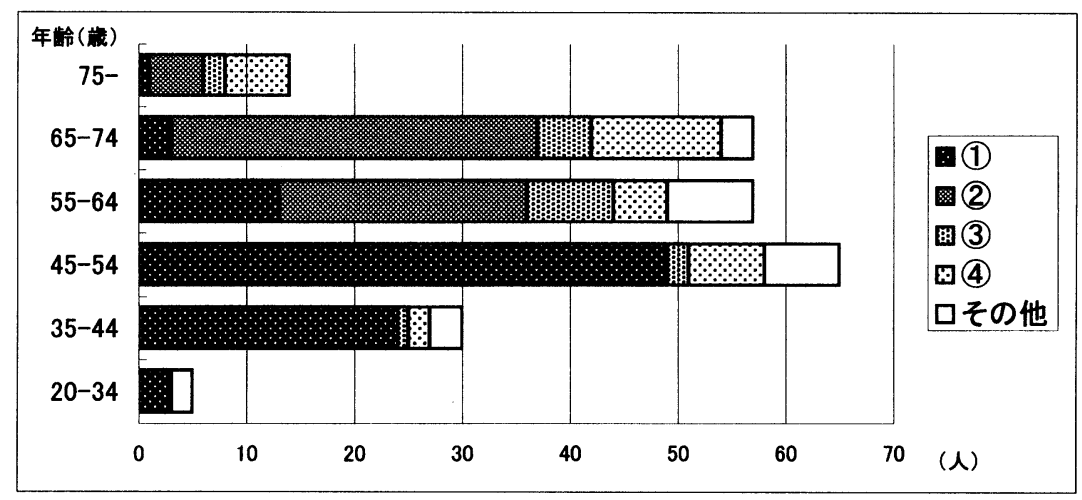

第 5 図 西ノ島 3 集落における年齢別就業パターン別就業者数

資料：聞き取り調査による

注）就業パターン番号は原則として本稿で示した 4 つの類型に準ずるものである。

(1)：まき網船団に就業するもの。

(2)：加齢とともにまき網船団から引退し，自営漁船漁業を営むもの。

(3)：若年・壮年期から自営漁業に従事すると同時に, 他産業との兼業を営むもの。

(4): 若年・壮年期から自営漁業へ専業・特化するもの。

「その他」の場合は, 巻き網船団以外の漁業会社へ就業しているもの(1))や不明のものを 含めた。

227 人が存在しており，この調査によって西ノ 島の全体的な傾向はつかめる。これに加え, 西 ノ島の主要漁種であるまき網漁業, 採貝, 一本 釣り等に従事している漁家や, 船団経営者, 船 団従業員などに, 経営状況や労働投下, 後継者 に対する考えなどについて詳細な聞き取り調查 を行なった。この結果, 西ノ島の漁業従事者が とっている就業パターンは大きく以下の 4 つに 類型化できた。

(1)まき網船団をはじめとする漁業会社に就業 するもの。
(2)加齢とともにまき網船団から引退し, 自営 漁船漁業を営むもの。

(3)若年・壮年期から自営漁業に従事すると同 時に，他産業との兼業を営むもの。

(4)若年 ·壮年期から自営漁業へ専業 ·特化す るもの。

これらの年齢別に，それぞれの就業パターン をとっている漁業就業者を示したのが第 5 図で ある。ここではこれを参照しながら，この 4 つ の就業パターンについて検討する。 
1) (1)まき網船団をはじめとする漁業会社に就 業するもの

船団に属し賃労働を行うことで, 若年期から 高位安定的な収入を実現し, 生計を維持しょう とするものである。ある程度の体力があれば, 就業当初から地域の平均的な労賃よりもかなり 高い賃金や, 技術の習得が保証されており, 図 のように現在, 若年層の漁業従事者のほとんど がこの就業パターンをとっている。若年層の 「その他」の者の多くも, 船団以外の漁業会社 に勤務するものであり，賃金は船団よりも劣る ものの, 安定的な収入を実現しているという点 ではこのパターンに準ずる。

2 ) (2)加齢とともにまき網船団から引退し, 自 営漁船漁業を営むもの

図のように，55才を過ぎると船団を引退し自 営漁業に参入するものが多くなり, 高齢になる にしたがって船団従業者と自営業者の数は逆転 する。また, 現在の自営業者の中ではこの戦略 をとっているものが大半を占める。

船団員は加齢とともに昼夜逆転の生活にも体 力的な限界を迎え, 船団からの引退を迫られる 一方，55才を過ぎると手厚い船員年金が支給さ れ始める。彼らは引退によって大きな収入源を 失うわけであるが，年に 200 万円以上もの年金 が支給される中で, 親の漁船漁業を後継したり, 船団の退職金などを原資に購入した1トン程度 の船を利用し，一本釣りや採貝・採藻に参入す る場合が多い。彼らは年齢的にも子供の教育費 も必要なくなり, 大きな出費を迫られないなか で, 船員年金と自営漁業で一定の収入を得て, 生計を維持しているといえる。

ところで, これらの自営の漁船漁業に従事し てそれなりの水揚げを実現するには一定の経験
や熟練を必要とするが, 彼らは船団に現役で従 事していた間に，そのようなノウハウを身につ けている場合が多い。例えば船団の休漁日に, 自分や親，友人が所有する船で一本釣りに行っ たり, 漁法を教わったり, 小型船の免許を取得 することが多いからである。このように巻き網 船団は, 自営漁業を営むのに必要な資本や人脈, 技術の獲得において「インキュベーター」とで も言うべき大きな役割を果たし, 船団員の引退 後の所得の減少を補うための, 自営漁業への参 入を容易にしているのである。このように(2)の 就業パターンをとるための技術や資本, 資格と いった参入障壁は低い。

3 ) (3)若年・壮年期から自営漁業に従事すると 同時に, 他産業との兼業を営むもの

この就業パターンにおける兼業先としては, 自己の裁量で労働時間の配分を決めやすい畜産, 民宿経営, 大工や左官などの自営業であること が多い。確かに公務員や農協職員といった業種 も少なからず漁業に従事しているが, 彼らの多 くは労働時間も水揚げ高も趣味の域を出ず, 年 90日以上出漁していないために漁協の正組合員 にも入らない。ここで扱うのは漁協の正組合員 で, 生計戦略上漁業の意味が大きい世帯につい てである。

この就業パターンの場合, 漁法は兼業先の業 種によって異なる。すなわち, 兼業先の労働の 時間的拘束が大きい大工や左官などの場合, 漁 業はあくまでも副収入的な部門にとどまり，季 節労働的 · 臨時収入的な性格の強い素潜りが選 好される。ただし, 素潜りは特殊技能が必要で あり, 若い体力のある者に限られる。一方, 畜 産や民宿との兼業の場合, 漁業が収入の柱とな り, 一本釣りや採貝・採藻, その複合といった 
周年労働的性格が強まる。

しかしながら, 若年者が州村当初から自営漁 業に参入するためには，大きな障壁がある。自 営漁業においては船の所有など資本が必要であ るし，満足のいく漁獲をあげるには技術の習得 が欠かせない。したがって, 彼らの参入のため は親とともに一定期間, 協業するのが現実的で ある。しかし親子協業の際には，子の世帯の生 計を維持できるだけの水揚げが実現しなければ 参入は困難である。

島内で行われている釣りや採貝といった漁船 漁業は，基本的には就業者 1 人での漁獲を原則 とした零細なものであるうえ, 漁家としても漁 獲高の低迷を背景として, 新船導入など漁獲強 度を増すような資本投下にも消極的であるなか では，2 人以上が作業するとなると労働力の不 完全燃焼を起こしてしまう可能性が高い。こう したなかでは, 新規就業者も兼業先の収入に頼 る必要性が大きいのであるが，兼業先の畜産で も子牛価格が乱高下したり, 大工や左官, 民宿 の需要も減少している。したがって，そもそも 生業を複合させても若年者のいる世帯の生計を 維持するだけの安定的な収入を得ることが難し く, 現在, 若年・壮年期から兼業で漁業に携わっ ている世帯は少数である。

4 ) (4)若年 ·壮年期から自営漁業へ専業 - 特化 し, 生計を立てるもの

このような戦略をとる場合, 漁法としては主 に一本釣りや刺し網が選好され, 若い後継者が 世帯を維持していくために船の規模や資本装備 も大きくなる。船団などの会社組織に身を置か ず，自己の力で西ノ島で漁業に従事しょうとす る者はこのような戦略をとることがあるが，(3) で示したように, 現在このような後継者の参入
の条件は厳しい。腕が良く熱心な自営漁業者で も1000万円近くの漁獲高をあげるのは困難で, 漁獲量・魚価ともに低迷を続けるなかで新規の 若年者の参入は少なくなっている。

これら 4 つの就業パターンを採る人の割合は 集落によっても多少異なっており, 赤ノ江や浦 郷では(1)・(2)の就業パターンがほとんどを占め るのに対し, 船越では(3)昔から漁船漁業専業で 営むものが少なからず存在する。これらの違い にはさまざまな地理的, 歴史的要因が考えられ るが, 近年の若年層の漁業の就業状況や経営構 造については，集落による目立った差が無いた め,ここでは詳しくは述べない。

\section{（2）西ノ島の後継者問題の様相}

ここでは，上述の就業パターンを踏まえ，現 在地域の漁業の担い手の帰村状況を客観的に把 握する。今回の調査では赤ノ江, 船越, 浦郷の 3 集落の50歳以上の浦郷漁協正組合員がいる全 153世帯については, 子供の数やその就業先, 居住地なども聞き取り調査している。そのうち, 世帯の後継者が既にいる，あるいは現在はいな くても近い将来確実に帰る見込みがある世帯は, ちょうど 3 分の 1 にあたる 51 世帯確認された (第 2 表)。さらにそのなかで漁業を営む後継者 がいる世帯は20世帯認められた。これは全体の

第2 表 西ノ島 3集落における漁業及び世帯後継者の有無

\begin{tabular}{|c|r|r|}
\hline 全集落合計 (正組合員数 227名) & 世帯数 & 男子の数 \\
\hline 正組合員がいる世帯数 & 210 & \\
\hline 漁業就業者が50歳以上 & 153 & \\
\hline うち家の後継ぎがいる & 51 & 66 \\
\hline うち漁業の後継ぎがいる & 20 & 22 \\
\hline そのうち巻き網従業員 & 14 & 15 \\
\hline それ以外の漁業会社従業員 & 2 & 2 \\
\hline 自営漁業 & 2 & 3 \\
\hline その他・不明 & 2 & 2 \\
\hline
\end{tabular}

資料：聞き取り調査による 
13\%にあたり，全国平均を大幅に下回っている ことが明らかになった ${ }^{12)}$ 。次に就業形態ごとに， 後継者の帰村状況を見ることにしよう。

まず, 自営漁船漁業の就業者すなわち, (3) · (4)の就業パターンをとる20代，30代の就業者は ほとんどいない。西ノ島の場合，このような漁 家の世帯継承は 30 代までに起きるのが一般的で あるので，この数がゼロに近い現状では，後継 者の不在はきわめて深刻化しているといえる (第 5 図)。

こうしたなかで, 島内出身で漁業に就業して いる 20 代，30代は専ら巻き網船団に就業してい る。しかしながら, 図から分かるように35歳末 満の従事者は 3 人と際だって少ない。35歳〜 44 歳の従事者も24人で, 他の世代と比べると多い とはいえない。これに対し, 船団従事者が最も 多いのは次の 45 歳〜 54 歳の世代であり,この 3 集落の船団員の約半数を占める 54 人がこの世代 に属している。つまり，55歳以上になり年金が 支給され始める10年後にはその多くが船団を辞 めることが予想され，この 10 年間に大量の船団 従事者の補充が必要になることが分かる。した がって, 現在の従業員の確保の状況は船団の存 続のためには全く不十分だといわざるを得ない。 こうした状況が続けば巻き網漁業の存続が劦か されるだけでなく，船団を引退して移行する自 営漁業の担い手にも明らかな影響が及び, 自営 漁業は高齢期の副収入源としての意味すら失っ てしまう可能性がある。

12)農林水産省「自営漁業世帯の経営状況に関する 調査」によると, 海面漁業の自営漁業世帯の漁業 後継者がいる割合は,「漁業に従事している後継者」

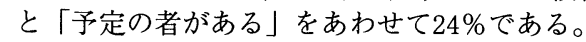

\section{（3）新規漁業就業者不在の原因}

ここでは，上述のような後継者不在の原因を 整理する。

まず，既に述べたように(3)・(4)の漁船漁業の 就業による帰村については, 水揚げ高の低さ, 不安定性に根本的な問題があると考えられる。 現状では後継者の参入があったとしても, 親子 2 世帯を養うだけの十分な漁獲を安定的に実現 するのは困難であり, 労働力の不完全燃焼を起 こす可能性が高い。これを補うために兼業する としても兼業可能な自営業自体が衰退傾向を強 めている。こうしたなかで, 後継者の確保は困 難というのが, 地域の漁家のかなり共通した見 解である。このような自営漁家の後継者再生産 にまず必要になっているのは, 養殖などの新規 漁法の導入や他の生業との合理的な複合, 新た な制度などの試行錯誤を通じて, 漁家の所得の 向上と安定の操業体系や枠組みを模索すること である。

一方, 就業機会に乏しい島内において, 安定 的で高い賃金水準にある(1)の巻き網船団従業員 も, 地元出身者によっては十分には確保されて いない。これには所得以外の要因を考えざるを 得ない。実際には, 地元の若青年層や彼らの親 が, 漁業に対して否定的な見解や展望を持って いることが大きく影響していると考えられる。 今回の漁業従業員に対する聞き取りでも, 自分 の子供には漁業に就かせたくないという意見が 大半を占め, 船団に入ることに否定的な見解を 持っている。その理由としては作業の危険性や 漁業の見通しが暗い，などを挙げている。親の 多くは自らが船団に従事し，作業の辛さを経験 し, 巻き網漁業の最盛期を見ているために, 自 分の子供にはやらせたくないと口をそろえる。 島内で育った子供たちも, 幼少期から漁業の厳 
第 3 表 親に漁業就業者を持つもので，漁業 以外に西ノ島で就業した者の就業先

\begin{tabular}{|l|r|}
\hline 役場 & 9 \\
\hline 漁協 & 6 \\
\hline 土建業 & 5 \\
\hline 隠岐汽船 & 3 \\
\hline 造船業 & 2 \\
\hline 大工 & 2 \\
\hline 教員 & 2 \\
\hline その他 & 12 \\
\hline \hline 計 & 41 \\
\hline
\end{tabular}

資料：聞き取り調査による

しさや離島の生活の不便さを痛感し, 都会にあ こがれて本土の高校や大学を出てそのまま就職 することが多い。隠岐島後の水産高校を卒業し ても，西ノ島の船団に従事することは希で, 多 くは本土に就職する。第 3 表は調査した 3 集落 の漁業従業者を親に持っている子の漁業以外へ の就業先を示したものであるが，彼らは帰村す るとしても，公務や建設業を指向し，漁業は敬 遠している。年収だけでなく「漁業をやりたい か,やりたくないか。息子にやらせたいか，や らせたくないか」という心理的な条件で, 就漁 が大きく制限されていることが想像されるので ある。

\section{I ターン就漁の要因と今後の展望}

前章では, 西ノ島における漁業就業パターン
と「後継者問題」を明らかにした。これを踏ま え，西ノ島において近年見られるIターンによ る漁業就業の動きをとりあげる。まず，町や船 団が実施したI ターン事業の概要にふれたうえ で，Iターンがなぜ可能になり，さらに，西ノ 島の「後継者問題」に対して，I ターン事業が いかなる意味を持っていたのか, 今後これが地 域漁業にとってどのような可能性を持ちうるの か，検討する。

\section{（1）Iターン事業の概要と成果}

西ノ島で行われたI ターン事業は，(1)巻き網 船団をはじめとする漁業会社に就業するもの， を対象にするものであった。船団は，地元の若 青年層によっては従業者が充足されないなかで, それ以外の何らかの方法で, 従業者を確保する 必要に迫られていた。こうしたなか, 平成 7 年 に船団が漁協や町の協力を受けて，I ターンに よる船団への新規就業をもくろみ，首都圈や関 西を対象とした求人誌に求人広告を出している。 来島するI ターン者に対する待遇は, 労働や給 与といった条件が他の船団員と特別に異なると いうことはなかったが，150人以上から打診が あり, 船団が採用にあたった結果, 実際に平成 11 年 1 月現在，これらの地域から実に 28 人の船 団従業者が来村し（第 4 表）, 彼らのなかには 船長になる人材も育ってきた。彼らは単身者の

第 4 表 |ターン者の年齢別帰村状況と世帯構成，出身地の内訳

\begin{tabular}{|c|c|c|c|c|c|c|}
\hline & \multirow{2}{*}{$\begin{array}{l}\text { I ターンによる } \\
\text { 漁業就業者数 }\end{array}$} & \multicolumn{3}{|c|}{ 世 帯 構 成 } & \multirow{9}{*}{ その他 } & \multirow{9}{*}{ 出身地 } \\
\hline & & 独身 & 妻帯 & 妻十子 & & \\
\hline$\sim 19$ & 2 & 2 & & & & \\
\hline $20 \sim 24$ & 9 & 6 & & 3 & & \\
\hline $25 \sim 29$ & 4 & 2 & & 2 & & \\
\hline $30 \sim 34$ & 2 & 2 & & & & \\
\hline $35 \sim 39$ & 5 & 1 & & 4 & & \\
\hline $40 \sim$ & 6 & 2 & 2 & 2 & & \\
\hline 合計 & 28 & 15 & 2 & 11 & & \\
\hline
\end{tabular}

資料：西ノ島漁協資料による 
みならず妻や子を伴ったものまで島に定着して おり，家族も入れると 70 人が島に定着したこと になる。I ターン従業者の年齢は19才から50代 まで幅広いが, 平均年齢は31才と若い。現在も 西ノ島へのIターンに対する打診は絶えず，I ターン者の就業によって現在，どの船団におい ても船団従業者はいちおうの充足をみているの である ${ }^{13)}$ 。

\section{（2）Iターンによる就漁の成功の要因}

I ターンが成立し得た条件として，まず挙げ られるのが，漁業会社によってそれなりの安定 的な所得が保証されている点であろう。I 夕ー ン者に船団の貨金水準について尋ねると，20代 のIターン者にとってみれば年功的な賃金制度 をとらない船団の給与は，かなり魅力的に映る ようであり，「もうかるなら 1 回やってみよう か」というような単純な好奇心が就漁の動機に なっている場合も見られ，独身者が単身で来島 するケースが多い。一方，30代を過ぎて都市で の会社勤務をやめて来島した人たちにとっては, 都市部での前の職と比べたら給与が下がること も少なくないが，飲食費や家賃が低く抑えられ ることを考えると, 現在の貸金水準のもとでは 生活しづらくなったという意見はあまり聞かれ ない。

独身者はともかく家族を伴って来島する者に とっては, 所得の安定は不可欠な条件であり, これが来島の第一の前提条件になっている。こ

13) 本稿で就業パターンを分析した時点では，船団 に就業したIターン者はまだ正組合員として認め られていないことが多いため（しばらくすれば認 められるのだが)，I 夕ーン者の多くは現在(1)の就 業形態をとったものがいても，第 5 図のような分 析ではカウントされていないものと考えられる。 すなわち，第 5 図の分析はほほ対象を西ノ島出身 者に絞った分析と考えて良い。
れと同時に, 船団への就業は参入段階での技術 や資本が必要ないのも，Iターンを容易にして いる。

もちろん, このような就漁が起こり得たのは, 彼らの漁業就業に対する憧れがあったからに他 ならない。I ターンの船団従業者の属性につい ては第 4 表のように首都圈や関西方面から来島 する者が多くを占める。彼らの 3 分の 1 は大卒 で学歴が高く, 職歴も様々であり,「都会の煩 わしさに嫌気がさした」といった不満や「自然 の中で暮らしたい」「海の上で魚を相手に自分 の才覚と肉体で漁を行ってみたい」といった希 望を持っていた場合がほとんどである。確かに， I ターン者の中には20代の単身者を中心に， 「船酔いが治らない」「労働がきつい」「島内の 人間関係がうまくいかない」などの理由で短期 間で離職した例もあるが，既に都会で長年サラ リーマン生活を送ってきた妻帯者などは来島す る場合, 島で生活することに対しての相当の覚 悟が出来ていると言え，努力を重ねて技術の習 得も速いうえ向上心も高く, 島の社会にもとけ 込んでいる。このようにIターン者は，島民の 多くに見られる漁業に対する否定的な価値観と は異なる価値観を漁業に対して抱いている。

ここで興味深いのは, 同じ労働・賃金条件下 でも，西ノ島と縁のない都市出身の I 夕ーン者 は就業先としての船団を積極的に捉え, 島内出 身者は否定的に捉えるといういかにも皮肉な認 知の差異があることである。そして，このよう な認知が実際の漁業の就業状況に大きな影響を もたらしていることが示唆される。

\section{（3）Iターンによる就漁の可能性と課題}

このようにIターン事業は巻き網船団への就 業者確保に重要な意味を持っていたことが明ら 
かになった。しかし現在，それ以外の就業パ夕ー ンをとるIターン者は現れていないし，そもそ も船団への I ターンによる就漁が今後も持続す るのか定かでない。

そこで，ここではIターンによる新規就漁が, 今後の地域漁業の展開にどのような可能性や限 界を持っているのか, 検討したい。まず，Iター ンによる就漁が西ノ島で持続するかどうか検討 すると同時に，彼らの船団引退後の自営漁業へ の就業は実現しうるのか，さらにIターンによ る, 来島当初からの自営漁業への就業があり得 るのか検討する。

\section{1）Iターンによる就漁の持続性}

上述のようにUターンによる参入がわずかな 状態が続くのならば，今後の船団従業者の充足 についても専らIターンに依らねばならない。 そうした場合，I ターンによる船団への参入が 今後も持続するのかどうかを議論することが重 要になる。

現在の都市生活者の自然志向の高まりや, 労 働に対する価值観の多様化といった趨勢が立ち 消えになるとは考えにくく，Iターン者の送り 出し側，つまり都市側からの西ノ島への就業希 望は, 船団の不振による労働条件の大幅な悪化 等がない限り, 今後も続くと思われる。また, 船団によって保証されている給与体系や労働条 件は彼らを惹きつけるに足るものである。しか し西ノ島側の今後のI ターン者の受け入れ体制 は十分に整っているとは言えない。受け入れ体 制としてまず問題となるのは, 住宅の問題であ る。現在, I ターンで来島している人たちも， 町営住宅や空き家, 漁協の厚生施設を改造して 利用するなどやりくりして，何とか収容してい る状態で，現在ほぼ満杯である。特に家族を伴っ
たIターン者にとっては, 水洗率の低さや, 一 戸建ての住宅がないといった劣悪な居住環境は 大きな不満になっている。確かに西ノ島には空 き家は100戸以上あると言われているが，夏場 などに帰省利用されるので，簡単には明け渡し てもらえない状態であり，I ターン者をさらに 大量に受け入れるためには，抜本的な方策をもっ て彼らの住宅を確保する必要に迫られていると いえる。

当面の課題は住宅問題であるが，教育環境に ついての不満も多い。都市出身者の高学歴者が 多いI ターンにとっては，島では子供に十分な 教育を施せないことに不満を持っている場合が 多かった。また医療面では急病時の不安がある と同時に，普段は急を要さない耳鼻科や眼科の 医療を受けられない点が不満として挙げられて いる。これらの不満の中には, 従来の島の住民 が抱いていた不満とは異なる点も少なくなく, これに対応するには西ノ島で行われてきた従来 の生活環境整備だけでは不十分であろう。彼ら の不満を的確に把握し, 彼らを大量に受け入れ られるようなハード・ソフト面での整備を進め なければ，I ターンによる船団への就業の持続 は疑わしい。

2) I ターン者が加齢とともにまき網船団か ら引退し, 自営漁船漁業を営む可能性

船団従事者にI ターン者が増えているなかで, 彼らも50代後半より船団を引退し自営漁業へ移 行する就業パターン (2) へ移行し島内に定着 するのかどうかという点についても, 慎重に検 討されなければならない。

現在の I ターン者の来島理由の多くには「漁 業をやりたい」が挙げられ，彼らは漁業という 生業に魅力を感じている。また, 今回の調査で 
も，Iターンで来島した何人かに聞き取り調査 を行ったが，「自分の船が欲しい」「定年退職後 は小さい船と年金で生活したい」という考えが 多く聞かれた。このように基本的には I ターン 者も(1) 一(2)の戦略を採る強い意思を持っている といえ,これからの自営漁業の担い手として大 いに注目される。西ノ島の漁船漁業は外部にも 参入の門戸が開かれているうえ, 船団が自営漁 業を営むのに必要な資本や人脈, 技術の獲得に おいてインキュベーターのような役割を果たし ているため, 彼らの自営漁業への参入は難しく はない。船員年金制度の存続といった基本的な 前提があれば, 船団引退後の彼らの参入が実現 される可能性が強い。その場合, 自営漁業は収 入源として彼らの定住を支える大きな役割を果 たすであろう。

しかしながら注意しなければならないのは， そもそも彼らが高齢になっても実際に西ノ島で の生活や定住を望むかどうかである。彼らの永 らくの定住のためには上述のような I ターン者 の生活上の不満に何らかの対策を講じる必要が ある。

3）Iターン者が来島当初から自営漁業に従 事する可能性

西ノ島では漁協の組合員資格を得やすく, 制 度的には自営漁業への参入は容易であり, I ター ンによる就業希望も少なくないようであるが, 所得の低さ, 不安定性が原因で, 実際に就業し ているものはいない。しかしながら，もし前述 のような努力によって, 所得の低位不安定性が

14) 漁船漁業に対しても, 船団と同じく，あるいはそ れ以上に, 西ノ島の漁家の親は子供が自営漁業に 就業することに対して否定的な意見を持ち, 反対 を唱えることが多い。
克服されたとすれば，島内の漁家や息子の漁業 に対する否定的な認知が根強いなかで(4)，Iター ンによる就業に対する期待は大きくなると考え られる。

ただし，Iターンによる就業には大きな障壁 がある。先述のように，自営漁業への参入にお いては資本の蓄積と技術の修得が必要になるた め, 漁家の子弟は親とともに就業して，船や技 術を継承することが一般的である。ところが, I ターン者は一般に, 来島当初は資本も技術も そしいため，参入の障壁が非常に高い。彼らの 参入を促すにはこのような障壁を低めることが 重要であり, 例えば漁業技術や漁船の獲得にお いて, 一定期間, 地域の熟練した自営漁家と協 業してIターン者が技術を習得したり，地域内 で船を安価に融通しあうなど，この障壁を低め るような体制を築いていくことが重要であろう。

\section{5. むすび}

本稿では, 隠岐・西ノ島を事例として, 就業 構造と就業者再生産の問題点を検討したうえで, I ターンによる就漁がいかなる条件で可能にな り，それが地域漁業の存立にどのような意味を 持っているのか考察した。ここで明らかになっ た事実は，現在漁業が基幹産業になっている， 離島部をはじめとする多くの漁業地域の後継者 問題に対しても, ある程度共通した示唆や問題 点を呈示するものと考える。

まず, 漁業所得が不安定な自営漁船漁業には 新規就業が見られないのに対して, 安定的な雇 用形態・給与体系を持つ漁業会社に対しては I ターンによる参入が見られた点は重要である。 これは地域内に新規参入者に安定的な収入を保 証するような何らかの枠組みが築かれれば, 都 
市住民の参入といったかたちでの従業者の再生 産も実現されることを示しており，多くの後継 者不足に悩む他の多くの漁村の地域社会におい ても，これらの枠組みの構築は検討されるべき であろう。ところで，島 ${ }^{15)}$ は山口県や大分県の 漁村の事例をもとに, 漁業を志向した若年就業 者には，潜水漁や一本釣りなどの，参入規制が 緩いが経済的に不利な漁業への多数の就労が目 立つことを指摘しており，今回の調査とは異な る結果が明らかにされている。この相違の原因 としては，実際の漁獲高の違いなど，様々な要 因が考えられるが，島の事例地域では，地域労 働市場の拡大によって若年層の地域滞留が確認 されるなかで, 主に地域内の他業種からの参入 が見られたものであり，漁業が不振に陥っても 他業種への就業が比較的容易であるため，参入 に対しての心理的抵抗が少なかったのに対し， 本稿の対象地域とした離島部では, 就業機会が 大きく限定された地域であり，漁業の不振はす なわち島での生存を勈かすことになり，安定的 な給与が保証されない限りは，参入が差し控え られるといった，地域的な条件の差によるもの も大きいと考えられ，この点についてはさらな る分析が必要であろう。

次に,これらの枠組みが構築されたとしても, 自営漁船漁業へのIターンによる参入について は，技術や資本の獲得についての参入障壁の高 さが問題になる。単に開放的な組合員認定だけ でなく，この障壁を低めるような地域の体制， すなわち「漁家」の後継者にこだわることなく， 地域全体で漁業後継者を確保していく体制が必 要であろう。同様に, 自営漁業に参入する際の 資本や人脈，技術の蓄積を実現する「インキュ

15) 前掲 8 , (1)
ベーター」としての役割を果たしている船団の 機能も注目に値する。このような船団が存在し ない地域においても，自営漁業に参入を希望す る者に対して一定期間，何らかの技術や資本獲 得を実現するような機関を設けることは考えら れてもよかろう。

さらに，Iターンによる就漁が持続するには, 地域の住宅や医療, 教育といった生活環境の整 備が欠かせないことも明らかになった。彼らの 定住のために求められるニーズを把握し，応え ていく必要性は大きい。

最後に注意されるべきなのは，漁家の子弟や 島内出身者による若年・壮年労働力が十分に再 生産されていない原因として，単に年収の低さ という問題だけではなく，親子の漁業に対する 否定的な認知が大きく絡んでいる点である。現 在の状況は, この結果として都市からの I ター ンに頼らざるを得ないという歪んだ担い手再生 産の構造が現出しているとも言うことができ， 島内出身者が船団や自営漁船漁業に新規就業し ていくためには，島民自らの漁業に対する否定 的な見解・認知を改善していくことが極めて重 要であると言える。

本稿では, 漁業後継者問題を考える上でのい くつかの論点を呈示することができた。しかし， そのそれぞれについて十分に綿密で実証的な検 討をするには至っていない。特に個々の漁業就 業者の就業行動についてはさらに厳密な議論が 必要であるし，I ターンの事例については，彼 らの職歴や就業の動機などについて，さらに丹 念な聞き取りと分析を進める必要がある。これ らは今後の課題とするとともに, 今回明らかに なった事実がどこまで一般化されうるのかを検 討するためにも，筆者は今後も様々な地域社会 と漁業の就業構造, 後継者再生産のメカニズム 
を, さらに幅広く読みとる必要があると考えて いる。

〔付記〕調査に際しては重谷隆洋氏をはじめと する西ノ島町役場の方々, ならびに扇谷豪氏を はじめとする浦郷漁業協同組合の方々, さらに は聞き取りさせていただいた多くの漁家の方々 に，多大なご協力を賜りました。また，東北大 学の両角和夫氏, 農業総合研究所の合田素行氏, 西沢栄一郎氏, 漁港漁村建設技術研究所の松本 卓也氏, 児玉いずみ氏には調査の段階から多く のご教示とご協力を賜りました。この場を借り て御礼申し上げます。なお, 本研究の現地調查 にあたっては, 財団法人漁港漁村建設技術研究 所の助成を得ました。 